\title{
PENGGUNAAN WARNA DALAM DISAIN INTERIOR PERPUSTAKAAN TERHADAP PSIKOLOGIS PEMUSTAKA
}

\author{
Majidah $^{1}$, Dian Hasfera ${ }^{2}$, M. Fadli ${ }^{3}$ \\ 1) Department of Library Science, FHISIP-UT \\ majidah@ecampus.ut.ac.id \\ 2) Department of Library Science, FAH-UIN Imam Bonjol Padang \\ dianhasfera@uinib.ac.id \\ 3)Department of Library Science, FAH-UIN Imam Bonjol Padang \\ mfadli@uinib.ac.id
}

\begin{abstract}
Abstrak: Berbagai penelitian teoritis yang bekerja dalam disiplin ilmu yang berbeda telah mengkaji secara mendalam tentang warna, sifat-sifatnya, sistem, dan hubungannya dengan psikologis manusia.Diketahui bahwa arti warna jauh lebih luas dan dalam dari konsep sekadar lapisan cat pada permukaan, atau alat dekorasi.Warna adalah elemen dasar (utama) dari sebuah desain dan yang paling ekspresif, serta arti/makna yang disampaikan oleh setiap warna, dan efek psikologis pada manusia. Fenomena yang terjadi saat ini bahwa banyak perpustakaan dan taman baca masyarakat (TBM) yang mulai menyadari desain interior menjadi daya tarik utama dalam meningkatkan kunjungan pemustaka ke perpustakaan. Tingkat kenyamanan yang diberikan perpustakaan dapat mempengaruhi persepsi pemustaka terhadap perpustakaan, sehingga memotivasi pemustaka memandang perpustakaan tidak hanya sebagai tempat pinjam meminjam buku dan membaca tetapi juga sebagai pusat relaksasi rekreasi.Pemilihan warna yang tepat merupakan salah satu aspek kajian dalam merumuskan strategi untuk meningkatkan jumlah pemustaka, pihak perpustakaan harus memilih dan menggunakan warna yang mampu memotivasi pemustaka untuk belajar dan menikmati suasana perpustakaan.Warna memiliki peran penting memunculkan citra interior ruang, dimana sarana integrasi warna yang digunakan dalam desain interior umum, furnitur, dan aksesoris, untuk pembuatan karakter perpustakaan secara keseluruhan.Banyaknya minat yang nyata terhadap "identitas sebuah ruang” melalui warna, bagaimana hal tersebut dapat menambah sifat estetika dari sebuah desain interior ruang, dalam hal ini adalah perpustakaan. Merancang desain eksterior dan interior gedung perpustakaan harus mempertimbangkan karakteristik pemustaka dari aspek usia, jenis kelamin, dan budaya sekitar, terutama keputusan bijaksana dalam memilih warna yang sesuai dengan situasi kondisi perpustakaan.
\end{abstract}

Kata kunci:Psikologi warna, Desain Interior Perpustakaan, Pemustaka

\section{PENDAHULUAN}

Banyak faktor yang dapat dilakukan oleh pihak perpustakaan guna menarik minat masyarakat berkunjung ke perpustakaan. Diantaranya suasana penyambutan pemustaka dengan sikap ramah dan menyenangkan, memberikan kemudahan akses ke sumber daya yang diperlukan (koleksi dan fasilitas), daya tarik lingkungan termasuk aspek pendukung (misalnya café dan tempat ibadah).Selain faktor-faktor tersebut, saat ini banyak perpustakaan dan taman baca masyarakat (TBM) 
yang mulai menyadari bahwa desain interior menjadi daya tarik utama dalam meningkatkan kunjungan pemustaka ke perpustakaan. Tingkat kenyamanan yang diberikan perpustakaan dapat mempengaruhi persepsi pemustaka terhadap perpustakaan, sehingga memotivasi pemustaka memandang perpustakaan tidak hanya sebagai tempat pinjam meminjam buku dan membaca tetapi juga sebagai pusat relaksasi rekreasi.

Dalam desain interior, selain rancangan bangunan, tata letak ruang (layout) serta furniture yang digunakan, warna menjadi salah satu aspek utama. Warna diyakini sebagai pengalaman visual manusia yang paling penting (Dzulkifli \& Mustafar, 2013), dan berfungsi sebagai saluran informasi yang kuat untuk sistem kognitif manusia dan berperan penting dalammeningkatkan kinerja memori. Sehingga dalam merumuskan strategi untuk meningkatkan jumlah pemustaka, pihak perpustakaan harus memilih dan menggunakan warna yang mampu memotivasi pemustaka untuk belajar dan menikmati suasana perpustakaan (Wichmann, Sharpe, \& Gegenfurtner, 2002).

Warna digunakan hampir secara universal dalam berbagai aspek kehidupan manusia, termasuk ranah pendidikan dalam memproduksi bahan ajar, seperti slide, strip film,gambar bergerak, program video. Terlihat bahwa bahan ajar tercetak dan instruksi berbantuan komputer hamper selalu diproduksi dalam warna. Apakah dalam bentuk file (softcopy), dalam bentuk cetak atau bahkan cat di dinding kelas, warna dapat mempengaruhi kemampuan siswa untuk belajar. Namun menurut Nazzaro (2008) atribut ini sering digunakan tanpa pertimbangan, sedangkan sebuah warna yang sesuai untuk presentasi Power Point atau tutorial apa pun akan menjadi motivasi dan dorongan untuk belajar.

Warna mengacu pada kekuatan simbolis dan kognitif untuk memengaruhi pembelajaran, memfasilitasi menghafal dan identifikasi konsep. Warna juga mempengaruhi cara kita melihat dan memproses informasi, sehingga dapat meningkatkan kemampuan untuk mengingat kata dan gambar (Myers 2004). Selanjutnya dalam bidang pendidikan warna dapat memainkan peran positif mempengaruhi peserta didik dan retensi kognitif (Dzulkifli \& Mustafar, 2013).

Untuk meningkatkan penggunaan perpustakaan serta kunjungan pemustaka, perlu diketahui bagaimana warna mempengaruhi suasana dan layanan perpustakaan, serta pertimbangan warna apayang terbaik untuk tingkat usia, jenis kelamin dan situasi kondisi pada lingkungan tertentu. Sangat penting bagi pustakawan untuk mengetahui bagaimana memilih dan menggunakan warna yang sesuai dan tidak bertentangan dengan visi misi perpustakaan. Lebih lanjut dalam artikel ini akan dibahas bagaimana psikologis warna dan pengaruhnya pada pemustaka.

\section{METODE PENELITIAN}

Berdasarkan uraian pendahuluan di atas, maka dalam tulisan ini yang akan dibahas lebih lanjut adalah konsep warna serta dampak 
psikologisnya terhadap pemustaka dalam rangka merumuskan strategi meningkatkan jumlah pemustaka ke perpustakaan.

Penelitian ini merupakan penelitian yang berangkat dari fenomena dilapangan kemudian dianalisis dan dikembangkan berdasarkan literatur atau referensi yang berkaitan dengan topik pembahasan, dengan menggunakan metode kajian literatur. Studi literatur atau kajian literatur dilakukan dengan mempelajari berbagai buku referensi serta hasil penelitian sebelumnya yang sejenis, menggunakan teknik pengumpulan data dengan mengadakan studi penelaahan terhadap bukubuku, literatur-literatur, catatan-catatan, dan laporan-laporan yang ada keterkaitannya dengan masalah yang diteliti atau yang akan dipecahkan, dan pembahasannya biasanya berkaitan dengan budaya, nilai dan norma yang berkembang pada situasi sosial yang diteliti, dengan tujuan untuk membentuk sebuah landasan teori pada sebuah penelitian (Nasir, 1988; Arikunto, 2006: Sarwono, 2006; Sugiyono 2016). Sejalan dengan konsep tersebut, Barbara Kitchenham (2004) menyebutkan bahwa dalam kajian literatur berarti melakukan penelitian dengan mengidentifikasi, mengevaluasi dan menafsirkan literatur-literatur yang relevan sesuai dengan topik pembahasan yang diteliti.

\section{HASIL DAN PEMBAHASAN}

Warna merupakan elemen yang mendasar dari desain lingkungan. Ini terkait dengan reaksi psikologis, fisiologis, dan sosial manusia, serta estetika dan aspek teknis dari lingkungan buatan manusia. Memilih warna untuk pengaturan tertentu tergantung pada beberapa faktor termasuk lokasi geografis, karakteristik potensi pengguna (budaya dominan, usia, dll.), jenis kegiatan yang mungkin dilakukan di lingkungan tersebut, alam dan karakter sumber cahaya, serta ukuran dan bentuk ruang (Tofle, 2004). Aspek kajian dan penelitian terkait dengan psikologi warna telah membuktikan adanya hubungan antara warna, individu dan pengaruhnya, meskipun sampai saat ini adatidak ada penelitian khusus tentang bagaimana kombinasi warna memiliki pengaruh yang berbeda dalam lingkup terbatas yang digunakan pada kategori visualisasi informasi (Bartram, 2017).

\section{Psikologi Warna}

Psikologi warna merupakan bidang kajian yang meneliti interaksi antara warna, kognisi, dampak yang ditimbulkan dan perilaku, dengan mempertimbangkan faktor budaya (Cyr, 2010; Madden, 2000), respon emosional (Valdez, 1994; Kwallek, 1988) dan pengaruh perilaku khususnya di sekitar respons konsumen (Bellizzi, 1992; Labrecque, 2012; Lichtle, 2007). Berbagai penelitian menunjukkan bahwa warna "hangat" (merah, kuning dan oranye) adalah lebih membangkitkan dari pada rona “dingin” biru dan hijau (Bellizzi, 1992; Mehta, 2009). Merah dianggap panas, bersemangat dan intens lintas budaya (Elliot, 2014; Labrecque, 2012; Madden, 2000), dan kemungkinan besar memicu gairah 
serta kecemasan (Kwallek, 1988). Kuning, oranye dan coklat kurang memiliki konsistensi respon afektif, meskipun nuansa kuning juga dianggap menarik. Terkait dengan warna, situs web untuk e-commerce lintas budaya menemukan bahwa responden tidak suka kelompok warna kuning dan menyebutnya sebagai warna yang "terlalu mencolok" dan tidak "tepat” ataupun "professional” (Cyr, 2010). Sebuah studi juga mengaitkan warna cokelat dengan "sedih" dan peringkat “basi”(Madden, 2000). Biru, dan sedikit banyak hijau, memiliki hubungan positif dengan dunia alami, berhubungan dengan konten positif (Madden, 2000; Elliot, 2014; Mehta, 2009; Elliot \& Object, 2008). Secara khusus, biru sangat kuat terkait dengan kedamaian dan ketenangan lintas budaya (Cyr, 2010; Madden, 2000). Dalam periklanan, biru dikaitkan dengan kepercayaan (Cyr, 2010) dan kompetensi (Labrecque, 2012), dapat membangkitkan impuls beli yang lebih kuat dari pada merah(Bellizzi, 1992). Kebalikan makna dalam warna kamar, biru lebih cenderung dikaitkan dengan depresi, dan merah dengan kecemasan (Kwallek, 1988).

Sebagian besar psikologi warna lebih fokus pada rona daripada chroma dan lebih ringan, meskipun hasil studi terbaru menunjukkan pengaruh warna soft dan chroma pada respons afektif (Lichtle, 2007). Chroma tinggi warnanya menarik dan intens; warna chroma rendah lebih tenang dan kurang dominan. Abu-abu digambarkan "serius" dan “professional”.Warna soft dikaitkan dengan ketenangan: dianggap lebih menyenangkan, kurang membangkitkan semangat dan kurang dominan dari warna gelap (Labrecque, 2012; Lichtle, 2007). Hitam dimaknai negatif dandominan (Madden, 2000; Valdez, 1994) coklat tua diartikan sedih.

Dalam satu penelitian, ditemukan bahwa subjek kurang marah ketika mereka membaca berita tentang pembunuhan dengan pada kertas warna pink mudadari pada kertas putih (Valdez, 1994). Temuan-temuan ini mungkin berguna saat pilihan rona dibatasi oleh branding, karena nuansa warna softdan chroma dapat diubah tanpa melanggar makna kategorikal atau "kepribadian” yang diinginkan (Mehta, 2009).

\section{Manfaat Warna Bagi Kesehatan Mental}

Tidak saja memiliki makna tertentu, warna juga bermanfaat bagi kesehatan mental dan jiwa seseorang. Mahnke (1996) merekomendasikan beberapa hal untuk kesehatan mental pada pusat dan rumah sakit jiwa:

1. Spesifikasi warna untuk koridor fasilitas mental, kamar pasien, dan ruang pemeriksaan harus mengikuti pedoman dan sesuai degan fasilitas medis lainnya secara umum. Namun, penekanannya harus pada penghapusan “kelembagaan” atau “makna” nuansa rumah sakit jiwa. Perancang harus berusaha untuk menciptakan lebih banyak suasana "rumah ideal”. 
2. Area rekreasi, lounge, dan terapi kamar okupasi harus dalam warna-warna ceria dan merangsang yang dipilih khusus untuk melayani fungsi masing-masing area. Beberapa imajinasi harus memandu pilihan desain dalam area rekreasi, terutama untuk anak-anak dan remaja.

3. Kamar sepi atau sunyi seharusnya tidak terlihat seperti lingkungan hukuman. Jika seorang pasien harus diisolasi, diaharus berada di tempat yang nyaman, tenang. Bukan pada kondisi sepi, mencekam dan tersudutkan. Ruangan harus memberi kesan perlindungan, dan pemulihan bukan hukuman. Sensorik yang berlebihan harus dihindari dan relaksasi dilanjutkan dengan warnawarna keren. Pilih warna dengan hatihati, sehingga mereka tidak akan terlihat institusional. Penerangan harus berada di sisi hangat. Hindari pencahayaan yang terlalu seragam, karena hal ini tidak menghasilkan bayangan. Bayangan adalah alam pengalaman dalam lingkungan dan membantu mendefinisikan aspek tiga dimensi. Di sisi lain, bayangan tidak boleh terlalu ekstrim untuk membuat efek yang mungkin mengganggu.

\section{Warna dalam Desain Interior Perpustakaan}

Konsep arsitektur dan interior di perpustakaan telah banyak berubah, terlihat dari bentuk, warna dan konsep yang digunakan dalam proyek terbaru dan solusi interior di berbagai perpustakaan di seluruh dunia. Menurut Juhnevica \& Udre (2010), kebutuhan pengguna, perencanaan ruang interior dan interior fisik desain lingkungan harus menjadi pusat dari proses perencanaan. Masa depan perpustakaan harus dilayani oleh berbagai peran komunitas dan masyarakat. Namun, keberhasilan desain akan diraih jikatercipta kepuasan pengguna tentang bagaimana lingkungan interior fisik memengaruhi mereka. Latimer (2007), menunjukkan bahwa, ruang pengguna perlu direncanakan dengan baik, ramah dan menarik sebagai peran fisik perpustakaan dan kebutuhan pengguna yang telah berubah di abad ke-21. Desain interior dan solusi arsitektur dapat menjadi penting dalam menciptakan tempat yang ramah untuk pengguna perpustakaan (pemustaka).

Di beberapa negara, perpustakaan mungkin satu-satunya ruang fisik untuk belajar dan berbagi informasi dalam konteks noninstitusional. Cara yang ideal untuk merancang perpustakaan merujuk pada ruang komprehensif dan multifungsi yang menggabungkan konsep ruang pembelajaran dan pendidikan seumur hidup, pusat pembelajaran dengan teknologi tinggi, yang melayani masyarakat dengan menawarkan tempat pertemuan (perpustakaan) intensif dan kolaboratif di bawah atap yang sama. Perpustakaan yang dibangun dan dikelola dengan pemikiran ini dapat menjadi sebuah tempat menarik untuk partisipasi informasi dan pembelajaran mandiri seumur hidup (Eigenbrodt, 2009). 
Lebih jauh, pengembangan konsep dengan faktor ambient, menciptakan bangunan perpustakaan haruslah evolusioner lingkungan interior (Bitner M. J., 1990). dengan inspirasi desain dan fiturbaru yang Menurut (Anandasivam \& Cheong, muncul sebagai perubahan kebutuhan masyarakat.

Desain perpustakaan tidak hanya tentang tetapi juga mencakup ruang dan lingkungan interior fisik yang praktis dan menarik. Satu salah satu aspek terpenting untuk mendesain perpustakaan adalah dengan mempertimbangkan lingkungan interior fisik yang terdiri dari perencanaan ruang interior, dan suasana interior seperti pemilihan penerangan, furnitur, bahan dan finishing (Sufar, 2012).

Lingkungan interior fisik adalah salah satu masalah utama yang terus diperdebatkan dan dibahas untuk menciptakan desain dan daya tarik yang lebih baik bagi pengguna. McCabe \& Kennedy (2003), point di luar itu, gedung perpustakaan harus menarik dan indah dipandang mata. Secara internal, itu harus fungsional dan terkini dalam penggunaan layanan pendukung teknologi untuk komunitasnya. Desain fitur arsitektur menyediakan tampilan fisik. Deskripsi yang mengikuti akan muncul untuk berbaur dengan masalah daya tarik dan efektivitas, yang terkadang tidak dapat dipisahkan. Deskripsi tersebut berlaku baik untuk bangunan baru maupun bangunan yang membutuhkan renovasi. Lingkungan fisik meliputi kedua elemen arsitektur seperti tata letak fisik, furnitur, dan peralatan dan elemen sensorik visual seperti warna, tekstur, dan pencahayaan. Dua aspek ini, 2008), tantangan terbesar adalah bagaimana memperoleh lebih banyak remaja danorang dewasa muda untuk datang ke perpustakaan. Perpustakaan perlu menjadi "keren" dan nyaman sehingga remaja dapat menganggapnya sebagai tempat yang baik untuk pertemuan dan berkumpul bersama. Anak-anak muda lebih suka tempat kerja yang nyaman dan lebih banyak kebebasan untuk bergerak dan menjelajahi ruang; mereka membutuhkan tempat untuk gunakan laptop dan zona berbeda untuk bekerja. Banyak anak muda lebih suka bekerja di ruang terbuka bersama dengan yang lain, meskipun masih ada beberapa dari mereka ingin bekerja di kamar yang sunyi. Ada juga kebutuhan besar untuk diam di perpustakaan (Juhnevica \& Udre, 2010).

Selanjutnya, perpustakaan perlu memiliki semua peralatan teknologi untuk mempermudah kinerja pustakawan. Banyak cara yang menarik bagaimana membuat gedung perpustakaan lebih nyaman dan aman (Juhnevica \& Udre, 2010).

Penting untuk memahami peran lingkungan interior fisik pada persepsi pemustaka dalam menciptakan desain yang lebih baik. Untuk mencapai desain publik yang lebih baik bagi perpustakaan, aspek kriteria fisik dan lingkungan harus ditekankan sejak awal pada bagian perencanaan. Dengan memahami semua pengaruh pada persepsi dan harapan pemustaka untuk menciptakan desain 
yang lebih baik, pembuat keputusan dapat memastikan bahwa pendekatan mereka terhadap elemen-elemen ambient dan fisik dalam keahlian mereka berinteraksi dengan tepat dan meningkatkan pengaruh lain pada pengalaman total pemustaka dan perilaku. Ini lebih dari sekedar fungsi dan estetika dari desain ambient dan fisik, tetapi juga pengaruh temporal, interaksi sosial dan konsekuensi psikologis.Untuk itu, menciptakan dan mencapai desain yang lebih baik untuk perpustakaan umum di masa depan maka berbagai aspek lingkungan interior fisik dan suasana interior harus dipertimbangkan seperti perencanaan ruang, pemilihan furnitur, penerangan, material dan finishing.

\section{Dampak Warna Terhadap Psikologis Pemustaka}

Kualitas layanan dan kepuasan pemustaka serta persepsi kualitas layanan sangat dipengaruhi oleh reaksi psikologis pemustaka: termasuk emosi, suasana hati, dan sikap. Lingkungan interior memiliki kemampuan yang kuat untuk menghasilkan emosi dan emosi tersebut memengaruhi persepsi pemustaka terhadap kualitas layanan (Sufar, 2010).

Reaksi psikologis pemustaka terkait erat dengan input ambient yang tersedia di bagian layanan dan kualitas fisik lingkungan layanan. Pengaruh psikologis juga terkait dengan rasa, waktu dan interaksi sosial.Untuk memahaminya seperti dikatakan McCabe, G. B. (2003), harus mempelajari efek psikologis warna. Gelap warna dapat menundukkan perilaku bersemangat, warna cerah akan merangsang. Menurut Gold Coast City Council Branch Libraries (GCCC), haruslah menggunakan pendekatan kontemporer untuk pemilihan warna dan bahan yang diadopsi untuk membangkitkan citra yang ramah dan mengundang dengan rasa efisiensi, ditambah dengan motivasi pengalaman membangun yang mengesankan dan kehadiran warga negara. Gedung perpustakaan baru seharusnya menunjukkan estetika garis yang bersih, didukung oleh pendekatan berlapis, berstekstur dan abadi untuk warnadan bahan langitlangit.Warna harus dimasukkan secara selektif dan didasarkan ada "latar belakang” netral.

Warna dapat ditampilkan pada elemenelemen seperti dinding dan partisi yang dipilih, pemilihan kain untuk furnitur dan penggunaan elemen grafis untuk secara jelas mendefinisikan area berbeda dari perpustakaan. Sementara itu karakteristik warna serta dampak psikologisnya terhadap permustaka terlihat dari tabel dibawah ini.

Tabel 1. Karakteristik Warna dan Dampak Psikologinya (Zelanki \& Fisher, 2003)

\begin{tabular}{|c|c|}
\hline $\begin{array}{c}\text { KARAKTERISTIK } \\
\text { WARNA } \\
\end{array}$ & DAMPAK PSIKOLOGIS \\
\hline I. & $\begin{array}{l}\text { MERAH, KETIKA DIGUNAKAN DI } \\
\text { INTERIOR, DAPAT DIKATAKAN } \\
\text { MENYEBABKAN KEGEMBIRAAN DAN } \\
\text { SECARA NEGATIF MEMPENGARUHI } \\
\text { PERSEPSI WAKTU DAN MENGARAH } \\
\text { KEGANGGUAN } \text { TIDUR. } \\
\text { PSIKOLOGIS DAN FISIOLOGISNYA, } \\
\text { DAPAT DIKLAIM BAHWA MERAH } \\
\text { KETIKA DIGUNAKAN DI DINDING ATAU } \\
\text { LANGIT-LANGIT, } \\
\text { MENYEBABKANGANGGUAN } \\
\text { BERKAITAN DENGAN WAKTU ATAU } \\
\text { KURANGNYA } \\
\text { KEMARAHAN DI PIHAK INDIVIDU. DI } \\
\text { SISI LAIN, WARNA MERAHDIKAITKAN } \\
\text { DENGAN KEHANGATAN, INTERIOR }\end{array}$ \\
\hline
\end{tabular}




\begin{tabular}{|c|c|c|c|}
\hline $\begin{array}{c}\text { KARAKTERISTIK } \\
\text { WARNA }\end{array}$ & DAMPAK PSIKOLOGIS & $\begin{array}{c}\text { KARAKTERISTIK } \\
\text { WARNA }\end{array}$ & DAMPAK PSIKOLOGIS \\
\hline & \begin{tabular}{lrrr} 
YANG & DOMINAN & DALAM & WARNA \\
MERAH & DAPAT & DIANGGAP & LEBIH \\
HANGAT & DARIPADA & YANG \\
\multicolumn{2}{l}{ SEBENARNYA. } & & \\
& &
\end{tabular} & V. ORANGE & $\begin{array}{llrr}\text { KARENA } & \text { ORANYE } & \text { ADALAH } & \text { HASIL } \\
\text { DARI } & \text { KOMBINASI } & \text { KUNING } & \text { DAN } \\
\text { MERAH, EFEKNYA } & \text { PADA INTERIOR } \\
\text { JUGA } & \text { MERUPAKAN } & \text { KOMBINASI }\end{array}$ \\
\hline \multirow[t]{2}{*}{ II. KUNING } & 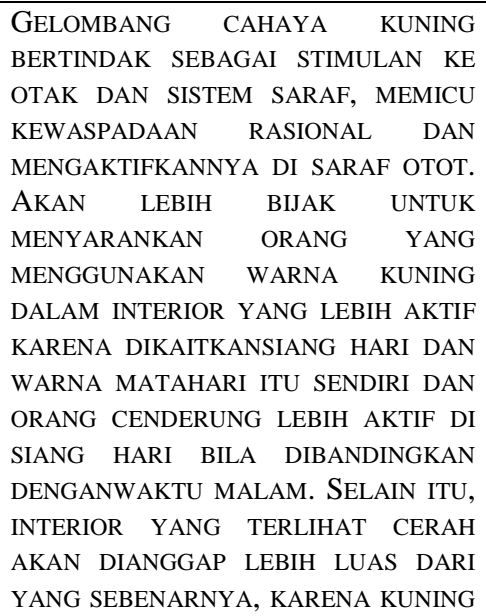 & & $\begin{array}{l}\text { DARIDUA. MENGAMBIL PENGARUH } \\
\text { STIMULAN MERAH DAN OPTIMISME } \\
\text { KUNING, DAPAT DIKATAKAN BAHWA } \\
\text { ORANYE } \\
\text { MENCIPTAKANSUASANA } \\
\text { KEINGINTAHUAN DAN KEGELISAHAN. } \\
\text { FITUR LAIN YANG MIRIP DENGAN } \\
\text { KUNING ADALAH AKAN MEMBUAT } \\
\text { TEMPAT ITU TERLIHATLEBIH CERAH } \\
\text { SAAT DIGUNAKAN DI DINDING DAN } \\
\text { LANGIT-LANGIT. SEPERTI WARNA } \\
\text { MERAH, KETIKA DIGUNAKAN DI } \\
\text { INTERIOR, ORANYE AKAN MEMILIKI } \\
\text { EFEK STIMULASI. FAKTANYA, } \\
\text { MULTIVITAMIN YANG DIGUNAKAN } \\
\text { SEBAGAI STIMULAN BIASANYA } \\
\text { DIPRODUKSI DALAM WARNA ORANYE. }\end{array}$ \\
\hline & $\begin{array}{l}\text { ADALAH WARNA YANG HANGAT DAN } \\
\text { DIKAITKAN DENGAN MATAHARI, } \\
\text { ORANG AKAN MENGANGGAP TEMPAT } \\
\text { ITU SEBAGAI LEBIH HANGAT DARI } \\
\text { BIASANYA. }\end{array}$ & VI. UNGU & $\begin{array}{lrr}\text { PENGGUNAAN WARNA UNGU GELAP } \\
\text { DAPAT } & \text { MENYEBABKAN } & \text { SUASANA } \\
\text { DEPRESI. } & \text { PENGGUNAAN } & \text { NUANSA } \\
\text { CAHAYA } & \text { MENGHASILKAN } & \text { EFEK } \\
\text { FEMININ } & \text { PADA INTERIOR. PENGARUH }\end{array}$ \\
\hline \multirow[t]{2}{*}{ III. HIJAU } & \begin{tabular}{lrr} 
MENGINGAT & \multicolumn{2}{c}{ PSIKOLOGIS DAN } \\
FISIOLOGIS & HIJAU, & KETIKA \\
DIGUNAKAN DI & INTERIOR, & DAPAT \\
DIKLAIM BAHWA WARNA & HIJAU \\
MEMILIKI & EFEK & SANTAI, \\
MENENANGKAN & DAN & BAHKAN \\
MENYEGARKAN & PADA ORANG & YANG \\
MENGAITKAN & HIJAU DENGAN & ALAM
\end{tabular} & & $\begin{array}{l}\text { INI BERASAL DARI FAKTA BAHWA } \\
\text { UNGU BERARTI WARNA BUNGA DAYA } \\
\text { TARIK WANITA. KETIKA DIGUNAKAN } \\
\text { DALAM KOMBINASI DENGAN HITAM, } \\
\text { ITU MENCIPTAKAN EFEK KOSMIK. } \\
\text { SAAT DIGUNAKAN DENGAN WARNA } \\
\text { PUTIH, MEMBERIKAN MAKNA } \\
\text { KEMULIAAN. }\end{array}$ \\
\hline & 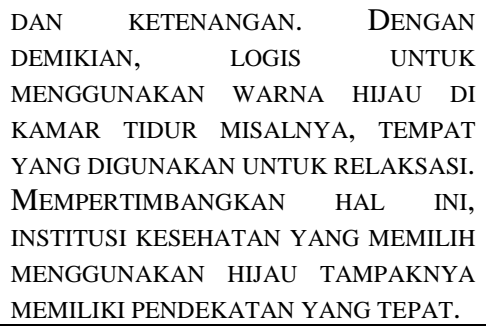 & COKLAT & 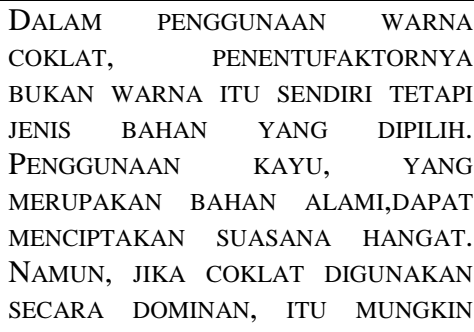 \\
\hline \multirow[t]{2}{*}{ IV.BIRU } & 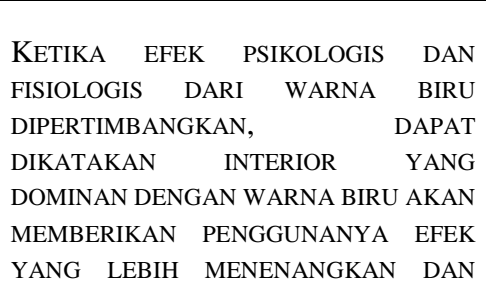 & & $\begin{array}{lrr}\text { MEMILIKI } & \text { EFEK } & \text { DETRAKTIF. } \\
\text { MAKANAN CEPAT SAJI RESTORAN } \\
\text { ADALAH CONTOH YANG BAIK UNTUK } \\
\text { DINDING INTERIOR COKELAT DI MANA } \\
\begin{array}{l}\text { PELANGGAN DIHARAPKAN UNTUK } \\
\text { MAKAN DENGAN }\end{array} \text { CEPAT DAN } \\
\text { PERGIDARIPADA } \\
\text { BERJAM-JAM. }\end{array}$ \\
\hline & $\begin{array}{l}\text { RILEKS JIKA DIBANDINGKAN DENGAN } \\
\text { WARNA } \\
\text { MERAH. BIRU DIANGGAP SEBAGAI } \\
\text { WARNA DINGIN DAN KARENA ITU } \\
\text { DIKAITKAN DENGAN DINGIN. } \\
\text { DEMIKIAN JUGA, EFEK YANG AKAN } \\
\text { DIBERIKAN PENGGUNANYA ADALAH } \\
\text { DINGINNYA. KEMUNGINAN } \\
\text { PENGGUNA AKAN MENGANGGAP } \\
\text { TEMPAT ITU LEBIH DINGIN DARIPADA } \\
\text { SEBENARNYA. }\end{array}$ & $\begin{array}{l}\text { VIII. HITAM, } \\
\text { PUTIH, ABU- } \\
\text { ABU }\end{array}$ & \begin{tabular}{lcr} 
KETIKA HITAM DIGUNAKAN DI SEMUA \\
DINDING DAN & LANGIT-LANGIT, IA \\
CENDERUNG & \multicolumn{2}{c}{ MENCIPTAKAN } \\
PERASAAN & TERTEKAN & KARENA \\
DIKETAHUI & MENYERAP & SEMUA \\
CAHAYA & YANG DITERIMANYA. \\
KETIKA & DIGUNAKAN & SEBAGAI \\
PENUTUP LANTAI, ITU BISA MEMBERI & MESAN KEDALAMAN.PUTIH, DI SISI \\
KESAN & KAIN, KETIKA DIGUNAKAN BAIK DI \\
LANGIT-LANGIT, DAPAT & DINDING DAN LANGIT
\end{tabular} \\
\hline
\end{tabular}




\begin{tabular}{|l|l|}
\hline $\begin{array}{c}\text { KARAKTERISTIK } \\
\text { WARNA }\end{array}$ & \multicolumn{3}{|l|}{ DAMPAK PSIKOLOGIS } \\
\hline & $\begin{array}{l}\text { MENGURANGI } \\
\text { PENGGUNAMEMAHAMI }\end{array}$ \\
KEHILANGAN PERSEPSI & TENTANG \\
KEDALAMAN. ALASAN MENGAPA & MENAN \\
WARNA INI SERING DIGUNAKAN DI \\
RUMAH SAKIT JIWA ADALAH UNTUK \\
MENCEGAH PASIEN SECARA TIDAK \\
SADAR MERASAKAN HAL YANG \\
BERBEDA. PENGGUNAAN ABU-ABU \\
DAPAT MENYEBABKAN PERASAAN \\
INDUSTRI DI INTERIOR. ABU-ABU, \\
YANG MERUPAKAN WARNA MESIN \\
DAN PERANGKAT DI PABRIK, DAPAT \\
MENCIPTAKAN SUASANA LOGAM DI \\
TEMPAT. \\
\hline
\end{tabular}

Beberapa hasil penelitian mengungkapkan dampak penggunaan warna terhadap pemustaka. Pertama, penelitian yang dilakukan oleh Santa Ulitua Gabriella Hutauruk (2016). Kesimpulan dari peneltian ini adalah perpustakaan umum daerah Jawa Barat memiliki warna yang kurang baik pada ruang baca dewasa. Warna netral menjadikan kesan ruangan yang kaku, monoton dan hampa yangdapat menyebabkan pengunjung perpustakaan merasakan bosan, jenuh serta mengantuk diruang baca dewasa. Tujuan utama dari warna perpustakaan adalah mencipta kondisi mood psikologi pengunjung yang berada diruang baca dan daya ingat untuk mengingat bacaan pengunjung dengan pengunjung perpustakaan. Berdasarkan landasan teori tersebut terlihat bahwa warna pada perpustakaan ini kurang memperhatikan akibat dari warna netral yang mendominasi seluruh area ke psikologi pengunjung yang berdampak pada tingkat perasaan hati seorang pengunjung yang berada dalam satu ruangan yang aktifitasnya membaca buku serta terganggunya konsentrasi dan daya ingat pengunjung pada isi buku bacaannya.

Sedangkan pada perpustakaan umum daerah Jawa Barat tujuan dari desain warna netral yang diterapkan perpustakaan tersebut setelah dicapai dengan baik diterapkannya desain warna yang menarik dan menambah estetika dari ruang baca dan area sekelilingnya. Akan tetapi pada kenyataannya warna netral diruang baca kurang mengarahkan pengunjung yang ingin menikmati suasana interior perpustakan untuk berlama-lama menikmati bacaan buku serta reverensi buku untuk tugas kuliah atau kampus.

Kedua, penelitian yang dilakukan oleh Suchi Mohanty (2002) pada tiga perpustakaan.

\section{Clemons Library, University of Virginia}

Perpustakaan Clemons menggabungkan elemen tradisional perpustakaan (membaca, belajar, dan menciptakan) dengan teknologi modern. Perpustakaan ini memiliki tata letak yang tidak biasa. Seperti yang direkomendasikan oleh literatur, beberapa meja dan area lounge diposisikan berdekatan dengan dinding berjendela. Hasilnya adalah area belajar yang nyaman.Skema warna lantai cukup netral. Karpet adalah campuran dari merah marun dan hijau, diimbangi dengan dinding berwarna krem dan bata. Cat Teal digunakan untuk menyoroti fitur tertentu dari ruangan seperti koleksi literatur penelusuran danarea mesin fotokopi. Rak sesuai ruangan, cocok dengan dinding bata warna merah marun dan hitam. Sebagian besar perabotan adalah kayu, yang melengkapi hampir setiap lingkungan. Satu-satunya variasi 
adalah tempat duduk lounge, yang dilapisi kain dalam pola biru dan hijau. Kombinasi warna biru dan hijau di lantai ini adalah pilihan yang bijaksana. Biru sering dikaitkan dengan peningkatan pemahaman belajar, sementara hijau mengurangi stres dan menyiratkan lingkungan yang aman.

\section{Johnson Center Library, George Mason}

\section{Library}

Perpustakaan ini beruntung karena berfungsi dengan banyak pencahayaan alami dari jendela besar dan lampu langit-langit termasuk dalam desain asli bangunan. Johnson Center dikelilingi oleh jendela clerestory, skylight, dan jendela gambar besar. Sebagian besar ruang belajar yang disediakan di luar perpustakaan tepat di ceruk-ceruk yang terang ini, menghilangkan kebutuhan untuk pencahayaan tambahan di siang hari. Namun, lampu individual akan melakukannya menjadi tambahan yang berguna untuk lampu langitlangit. Skema warna dari perpustakaan yang dikendalikan adalah netral, dengan warnawarna cerah digunakan sebagai aksen dalam furnitur dan dekorasi. Karpet adalah biru bisu dengan flek abu-abu dan kuning. Dindingnya dicat warna biru muda, yang intensitasnya bervariasi tergantung pada jumlah sinar matahari di daerah tersebut; di beberapa daerah bahkan tampak putih. Kuning flek di karpet beraksen oleh cat kuning yang digunakan untuk menyoroti area tertentu perpustakaan, seperti koleksi majalah. Semua kursi berlapis kain dalam nuansa biru dan abu-abu, cocok dengan karpet di perpustakaan, tetapi sebagian besar kursi santai dan sofa berwarna merah atau coklat. Meskipun kursi santai tidak cocok sisa skema warna perpustakaan, penggunaan merah efektif karena intensitasnya tersebar dalam satuan kecil. Untuk mengecat seluruh dinding atau tutup semua perabotan dengan warna merah kain akan luar biasa, tetapi dalam konsentrasi kecil konsep ini dapat dikelola. Rak semua terbuat dari logam hitam, pilihan bijak meminimalkan konflik dengan hiasan lainnya fitur.

\section{Lilly Library, Duke University}

Dibangun pada tahun 1927, Lilly Library pertama kali berfungsi sebagai perpustakaan untuk Women's College ofUniversitas Duke. Saat ini perpustakaan terutama melayani mahasiswa sarjana yang tinggal di Kampus Timur Universitas, mengumpulkan di bidang filsafat, baik, dan pertunjukan seni.Lilly juga menampung koleksi film perpustakaan (History of Lilly Library). Perpustakaan memiliki tata ruang yang sederhana-ada dua ruang belajar di lantai pertama, dan satu ruang belajar besar kamar di lantai dua. Tidak ada ruang belajar individu, dan meskipun adaarea belajar kecil di basement bangunan, mayoritas tempat duduk ada di yang pertama dan lantai dua. Ruang Baca Referensi didekorasi dengan gaya klasik, cara konservatif. Meskipun sangat indah, ini merupakan campuran elemen positif dan negatif. Sifat pencahayaan dan pemilihan warna berkontribusi besar pada suasana kamar. Ruangan ini memiliki kecenderungan ke arah kegelapan karena fitur dekoratif dari kamar. 


\section{PENUTUP}

Warna memiliki peran penting dalam dunia desain, dan mungkin saja sangat memengaruhi kehidupan manusia. Mengetahui efek psikologis warna adalah suatu keharusan bagi orang yang bekerja di berbagai bidang desain (arsitektur interior, desain grafis, iklan). Pilihan warna menentukan apakah efek psikologis, fisiologis dan sosial akan positif atau tidak. Terkait dengan perpustakaan, penting bagi pihak perpustakaan untuk memahami peran lingkungan interior fisik pada persepsi pemustaka, sehingga perpustakaan akan berusaha untuk menciptakan desain yang lebih baik. Untuk mencapai desain yang lebih baik bagi perpustakaan, pemilihan dan penggunaan warna harus ditekankan sejak awal dalam perencanaan ruang atau gedung perpustakaan.

Sesuai dengan uraian pembahasan, aspek warna sangat berpengaruh terhadap psikologis pemustaka, sehingga pemilihan warna yang tepat dalam desain interior perpustakaan dapat meningkatkan jumlah pemustaka yang datang ke perpustakaan, begitu juga sebaliknya. Artinya, dapat disimpulkan bahwa jumlah pemustaka berkaitan dengan penggunaan warna di perpustakaan.

\section{DAFTAR PUSTAKA}

Anandasivam, K., \& Cheong, F. C. (2008). Designing a Creative Learning Environment: NTU's New Art, Design \& Media Library. The Electronic Library Oxford, vol. 26, page 650.
ABellizzi, J., \& Hite, R. E. (1992). Environmental color, consumer feelings, and purchase likelihood. Psychology \&marketing 9, 5 (1992), 347-363.

Bartam, L., Patra, A., \& Stone, M. (2017). Affective Color in Visualization. Denver, CO, USA: CHI.

Bitner, M. J. (1990). Evaluating service encounters: the effects of physical surroundings. and employee responses. Journal of Marketing , 54 (2): 69.

Cyr, D., Head, M., \& Larios, H. (2010). Colour appeal in website design within and across cultures: Amulti-method evaluation. International journal of human-computer studies 68, 1 (2010), $1-21$.

Dzulkifli.M. \& Mustafar.M. (2013). The Influence of Colour on Memory Performance: A Review. The Malaysian Journal of Medical Sciences. 20(2),3. Retrieved from http://www.ncbi.nlm.nih.gov/pubmed/ ?term=MustafarMF

Elliot, AJ.,\& Markus, A. M. (2014). Color psychology: Effects of perceiving color on psychological functioning in humans. Annual review of psychology 65 (2014), 95-120.

Elliott, T., \& Objects, B. (2008). Why businessintelligence projects fail-And what to do about it. In Bus. Objects User Conf. Europe, Vol. 2009.

Hutauruk, S. U. G. (2016). Pengaruh Efek Warna Netral Di Ruang Baca Dewasa Terhadap Psikologi Pengunjung Bapusipda Jawabarat. e-Proceeding of Art \& Design : Vol.3, No.3 December 2016. Bandung: Telkom University.

Juhnevica, E., \& Udre, D. (2010). “Libraries Designed for Users” Nowadays Concept of Library Architecture and Interior. BOBCATSSS 2010 @ Parma, Italy .

Kitchenham, B. (2004). Australia: Department of Computer Science Keele University.

Kwallek, N., MLewis, C., \&Robbins, A.S. (1988).Effects of office interior color on workers' mood and productivity. 
Perceptual and Motor Skills 66, 1 (1988), 123-128.

Labrecque, L.I., \& Milne, G. R. (2012) Exciting red and competent blue: the importance of color in marketing. Journal of the Academy of Marketing Science 40, 5 (2012), 711-727.

Lichtlé, M. (2007).The effect of an advertisement's colour on emotions evoked by attitude towards the ad: The moderating role of the optimal stimulation level. International Journal of Advertising 26,1 (2007), 37-62.

Madden,T.J., Hewett, K, and Roth, M. S. (2000). Managing images in different cultures: A cross-national study of color meanings and preferences.Journal of international marketing 8, 4 (2000), 90-107.

Mahnke, F., and Mahnke, R. (1987).Color And Light in Man-Made Environments. New York: Van Nostrand Reinhold Co. Inc.

Mehta, R., Zhu, R. J. (2009). Blue or red?Exploring the effect of color on cognitive task performances. Science 323, 5918 (2009), 1226-1229.

Mohanty, S. (2002). Physical Comfort in Library Study Environments: Observations in Three Undergraduate Settings. Chapel Hill, North Carolina: University of North Carolina.

Myer Judy. (2004). The color of learning: enhance memory and retention with a splash of color. Retrievedfrom http://blogs.bnet.com/favicon.ico

Nazzaro, M. (2008).Colors and learning.In B. Hoffman (Ed.), Encyclopedia of Educational Technology.Retrieved from

http://coe.sdsu.edu/EET/articles/colorl earning.

Nazir.(1998). MetodePenelitian.Jakarta : Rineka Cipta

Sugiyono. (2013). Metode Penelitian Kuantitatif, Kualitatif dan $R \& D$. Bandung: Alfabeta

Tofle, R. B., Schwarz, B., Yoon, S., \& MaxRoyale, A. (2004).Color In H E A L THCAREEN VIRONMENTS. The Coalition for Health
Environments Research(CHER):

Author.

Valdez, P., \& Mehrabian, A. (1994).Effects of color on emotions.Journal of experimental psychology: General 123, 4 (1994), 394.

Wichmann F, Sharpe L, \& Gegenfurtner K. (2002).The contributions of color to recognition memory for naturalscenes.Canadian Journal of Experimental Psychology. 28(3), 509-520. Retrieved fromhttp://www.ncbi.nlm.nih.gov/pub med/20565178

Zelanski, P., Fisher, M. P. (2003). Color, Fourth Edition, Prentice Hall Inc. New Jersey. 